JPDN ISSN 2579-6461 (Online) ISSN 2460-6324 (Print)

Jurnal Pendidikan Dasar Nusantara

Volume 6| Nomor 1 | Juli 2020|

DOI: https://doi.org/10.29407/jpdn.v6i1.14754

\title{
MODEL PENUGASAN BELAJAR DI RUMAH YANG MENYENANGKAN BAGI SISWA DI MASA PANDEMI COVID 19
}

\author{
Slamet Basuki \\ slametbasuki35@gmail.com \\ SDN Sukorame 3 Kediri, Kec. Mojoroto, Kota Kediri \\ No Handphone: +6281703233559
}

\begin{abstract}
Abstrak: Artikel Model Penugasan Belajar di Rumah yang Menyenangkan bagi Siswa di Masa Pandemi Covid 19 ini merupakan artikel yang berisi gagasan (ide) bersumber dari pengalaman penulis dalam pembelajaran jarak jauh selama pandemi covid 19. Tujuan artikel ini yaitu; 1. Memberikan gagasan (ide) kreatif bagi Guru tentang model penugasan belajar di rumah yang menyenangkan bagi siswa di masa pandemi Covid 19; 2. Menjelaskan model penugasan yang menyenangkan bagi siswa di masa pandemi covid 19; 3. Guru dapat melaksanakan pembelajaran kreatif dan menyenangkan di masa darurat pandemi Covid 19; 4. Guru dapat melaksanakan penugasan kreatif dan menyenangkan di masa darurat pandemi Covid 19; 5. Sebagai kajian literasi dalam kesiapsiagaan menghadapi wabah pandemi Covid 19; Adapun metode dalam artikel model penugasan belajar di rumah yang menyenangkan bagi siswa di masa pandemic covid 19 berupa penjelasan penugasan belajar di rumah yang menyenangkan dengan beberapa poin yang diuraikan secara rinci.
\end{abstract}

Kata kunci: model penugasan, belajar menyenangkan, pandemi covid 19.

\section{A FUN HOME STUDY ASSIGNMENT MODEL FOR STUDENTS DURING THE COVID 19 PANDEMIC}

\begin{abstract}
This Fun Learning Home Assignment Model Article for Students in the Covid Pandemic Period 19 is an article that contains ideas derived from the author's experience in distance learning during the covid pandemic 19. The purpose of this article is; 1. Provide teachers with creative ideas (ideas) about learning assignments at home that are fun for students in the Covid 19 pandemic; 2. Explain a fun assignment model for students in the covid pandemic 19; 3 . The teacher can carry out creative and fun learning in the emergency of the Covid 19 pandemic; 4. Teachers can carry out creative and fun assignments during the Covid 19 pandemic emergency; 5. As a literacy study in preparedness to deal with the Covid 19 pandemic outbreak; The method in the article on the assignment model of learning at home that is fun for students in the pandemic covid 19 period is an explanation of the assignment of learning at home that is fun with a few points outlined in detail.
\end{abstract}

Keywords: assignment model, learning fun, covid pandemic 19. 
Slamet Basuki. Model Penugasan Belajar di Rumah

PENDAHULUAN

\section{Latar Belakang}

Indonesia dan negara - negara di dunia saat ini sedang dilanda musibah penyakit, yaitu Covid 19. Penularan wabah penyakit Covid 19 begitu cepat sehingga jumlah manusia yang terpapar penyakit Covid 19 di dunia sangat banyak, termasuk di Indonesia, yang mencapai ribuan sejak kasus pertama diumumkan pada 2 Maret 2020.(https://nasional.kompas.com/read/2020/03/03/06314981/fakta-lengkapkasus-pertama-virus-corona-di-indonesia?page=all)

Berbagai usaha untuk memutus mata rantai penyebaran wabah penyakit Covid 19, salah satunya adalah menghindari kontak fisik sesama manusia, misalnya tidak mengumpulkan orang, tidak bergerombol dan menghindari suatu kerumunan orang. World Health Organization (https://www.who.int/indonesia/news/novelcoronavirus/qa-for-public).

Dengan adanya wabah penyakit Covid 19 ini yang terjadi sejak bulan Maret 2020 memyebabkan berbagai dampak di Indonesia, salah satunya dunia pendidikan di Indonesia. Sekitar pertengahan bulan Maret 2020 pendidikan atau persekolahan di Indonesia meliburkan semua peserta didik sampai batas yang tidak ditentukan dan menerapkan pembelajaran jarak jauh melalui dalam jaringan (daring). Kegiatan belajar mengajar (KBM) dilaksanakan jarak jauh dengan cara daring (dalam jaringan) atau online, Guru mengajar dan memberi tugas dari rumah. Peserta didik belajar juga di rumah.

Permasalahan yang timbul yaitu peserta didik mengalami kesulitan menyerap materi pelajaran yang disampaikan Guru selama masa pandemi Covid 19. Peserta didik juga mengalami kesulitan melaksanakan tugas dari Guru dan terbebani dengan tugas - tugas dari Guru. Orangtua juga mengalami kebingungan untuk membantu putra - putrinya untuk mengerjakan tugas.

Penyebab permasalahan karena model pembelajaran dan model penugasan di masa normal atau tidak ada pandemi Covid 19 diterapkan dimasa darurat pandemi Covid 19. Sebagian Guru kurang siap dalam menggunakan model pembelajaran dan penugasan untuk masa pandemi Covid 19. Adapun solusi untuk permasalahan tersebut perlu sebuah gagasan (ide) desain model pembelajaran dan penugasan yang menyenangkan dimasa darurat pandemi Covid 19. 


\section{Slamet Basuki. Model Penugasan Belajar di Rumah}

Model Penugasan yang menyenangkan bagi siswa menurut (Ilham Rahardjo, 2020) memiliki 3 aspek terdiri atas. (a.) aspek bermanfaat yaitu penugasan belajar di rumah kepada siswa memiliki manfaat bagi siswa, keluarga, lingkungan sekitar, bahkan global, dengan adanya kebermanfaatan memotivasi siswa karena merasakan keuntungan atau kebaikan jika menyelesaikan tugas tersebut; (b.) aspek pemecahan masalah adalah tugas berisi suatu pemecahan masalah atau solusi atas permasalahan rumah dan lingkungan sekitar. Misal membersihkan kamar tidur, merapikan kamar tidur, membantu orang tua, dll. Tugas yang berkaitan solusi bisa menyesuaikan profesi orang tua, kondisi rumah, siswa mengikuti arahan orang tua dan disini orang tua bisa berperan sebagai guru; (c.) Untuk aspek ketiga atau terakhir penugasan belajar di rumah memiliki unsur kekinian atau sedang menjadi pembahasan / permasalahan saat ini. Saat ini karena lagi masa pandemi Covid 19 maka penugasan berkaitan dengan kecakapan hidup (lifeskill) dalam masa darurat pandemi Covid 19. misalnya membuat masker secara sederhana dan sesuai kreatifitas siswa, mencuci tangan yang benar, menjaga kebersihan, dll. Dalam memberikan penugasan guru sebaiknya memiliki dasar atau pijakan yang terdiri dari. (a.) Kompetensi Dasar (KD); (b.) Multiple Intelegences (MI); (c.) Pemecahan Masalah; dan (d.) Profesi orang tua sehingga setiap penugasan kepada siswa menjadi menyenangkan. Penugasan hendaknya disesuaikan psikologi siswa dalam hal ini memiliki keterkaitan dengan kecerdasan / intelenjensial siswa (Kecerdasan bahasa, logikal,matematikal, visual spasial, musikal, kinestetik,inter personal. Intra personal, naturalis, eksisensial).

\section{Tujuan}

Tujuan penelitian adalah untuk memecahkan permasalahan yang terjadi dilapangan, memuaskan rasa ingin tahu, dan mencari penegtahuan yang ilmiah (Alfianika, Ninit : 2018: 14) Adapun tujuan dari penulisan adalah sebagai berikut.

1. Memberikan gagasan kreatif bagi Guru tentang model penugasan belajar di rumah yang menyenangkan bagi siswa di masa pandemi Covid 19;

2. Menjelaskan model penugasan yang menyenangkan bagi siswa di masa pandemi covid 19;

3. Guru dapat melaksanakan pembelajaran kreatif dan menyenangkan di masa darurat pandemi Covid 19; 
Slamet Basuki. Model Penugasan Belajar di Rumah

4. Guru dapat melaksanakan penugasan kreatif dan menyenangkan di masa darurat pandemi Covid 19;

5. Sebagai kajian literasi dalam kesiapsiagaan menghadapi wabah pandemi Covid 19.

\section{METODE}

\section{Metode Penelitian}

Metode penelitian yang digunakan adalah metode penelitian kualitatif yang pengumpulan data pada suatu latar alamiah dengan maksud menafsirkan fenomena yang terjadi dimana peneliti adalah sebagai instrumen kunci, pengambilan sampel sumber data dilakukan secara purposive dan snowbaal, teknik pengumpulan dengan trianggulasi (gabungan), analisis data bersifat induktif / kualitatif, dan hasil penelitian kualitatif lebih menekankan makna dari pada generalisasi. (Anggito, Albi \& Setiawan, Johan, S. Pd. 2018: 8). Penelitian kualitatif bertujuan memahami realitas sosial, yaitu melihat dunia apa adanya, bukan dunia yang seharusnya. (Mamik, 2015:3)

Metode penelitian yang digunakan dalam model penugasan belajar di rumah yang menyenangkan bagi siswa di masa pandemi Covid 19 adalah metode penelitian kualitatif yang berfokus pada tingkat partisipasi siswa dalam menyelesaikan dan mengumpulkan tugas dari Guru. Tingkat partisipasi siswa diobservasi dan didokumentasikan ketika diberikan model penugasan belajar di rumah tanpa model penugasan belajar di rumah yang menyenangkan bagi siswa di masa pandemi Covid 19 dan dengan model penugasan belajar di rumah yang menyenangkan bagi siswa di masa pandemi Covid 19. Dari hasil observasi tersebut dapat ditarik simpulan penelitian.

\section{Prosedur Pelaksanaan}

Pelaksanaan penelitian model penugasan belajar di rumah yang menyenangkan bagi siswa di masa pandemi Covid 19 dilaksanakan sejak diberlakukan kegiatan belajar di rumah (BDR) berdasarkan Surat Edaran Menteri Pendidikan dan Kebudayaan No. 4 Tahun 2020 tentang Pelaksanaan Kebijakan Pendidikan Dalam Masa Darurat Penyebaran Coronavirus Disease (Covid 19) tertanggal 24 Maret 2020, (2020:2) Adapun hari dan tanggal pelaksanaan penelitian kegiatan belajar di rumah tanpa model penugasan belajar di rumah yang menyenangkan bagi siswa di masa pandemi Covid 19 adalah Senin - Sabtu, 13-18 April 2020 atau selama 6 hari, dan untuk pelaksanaan penelitian kegiatan belajar di rumah dengan model penugasan belajar di rumah yang menyenangkan bagi 
Slamet Basuki. Model Penugasan Belajar di Rumah

siswa di masa pandemi Covid 19 pada hari, tanggal; Senin - Sabtu, 20-25 April 2020 atau selama 6 hari.(Kurikulum Darurat : SDN Sukorame 3 Kediri: 2020) Selama kegiatan penelitian diobservasi dan didokumetasikan pengumpulan dan penyelesaian tugas siswa.

\section{Subyek Penelitian}

Subyek penelitian model penugasan belajar di rumah yang menyenangkan bagi siswa di masa pandemi Covid 19 adalah siswa kelas V SDN Sukorame 3 Kediri tahun 2019/2020 berjumlah 37 siswa dengan rincian $\mathrm{L}=16$ siswa dan $\mathrm{P}=21$ siswa. (Data Kelas 5, 2019: 2)

\section{Instrumen Penelitian}

Instrumen adalah alat atau fasilitas yang digunakan penelitian dalam mengumpulkan data agar pekerjaannya lebih mudah dan hasilnya lebih baik, sehingga mudah diolah (Arikunto, 2006: 16). Instrumen penelitian model penugasan belajar di rumah yang menyenangkan bagi siswa di masa pandemi Covid 19 menggunakan lembar observasi pengumpulan dan penyelesaian tugas ketika diberikan model penugasan belajar di rumah tanpa model penugasan belajar di rumah yang menyenangkan bagi siswa di masa pandemi Covid 19 dan dengan model penugasan belajar di rumah yang menyenangkan bagi siswa di masa pandemi Covid 19. Peran peneliti dalam melakukan observasi merupakan instrument kunci dalam penelitian ini. Peneliti merupakan key instrument dalam mengumpulkan data, peneliti harus terjun sendiri kelapangan secara aktif (Gunawan, 2013: 19). Dari hasil observasi tersebut dapat ditarik simpulan penelitian.

\section{Teknik Analisis}

Teknik analisis data dilakukan secara berkesinambungan dan untuk mempertajam fokus dan menguji keabsahan data (Helaluddin, Hengki Wijaya, 2019: 21) berdasarkan lembar observasi pengumpulan dan penyelesaian tugas ketika diberikan model penugasan belajar di rumah tanpa model penugasan belajar di rumah yang menyenangkan bagi siswa di masa pandemi Covid 19 dan dengan model penugasan belajar di rumah yang menyenangkan bagi siswa di masa pandemi Covid 19. Dari data yang diperoleh diambil persentase tingkat pengumpulan dan penyelesaian tugas belajar di rumah. Keberhasilan penelitian disimpulkan dari persentase yang tinggi ketika diberikan model penugasan belajar di rumah dengan model penugasan belajar di rumah yang menyenangkan bagi siswa di masa pandemi Covid 19. Perhatikan Gambar 1. Grafik Analisis Penelitian 
Slamet Basuki. Model Penugasan Belajar di Rumah

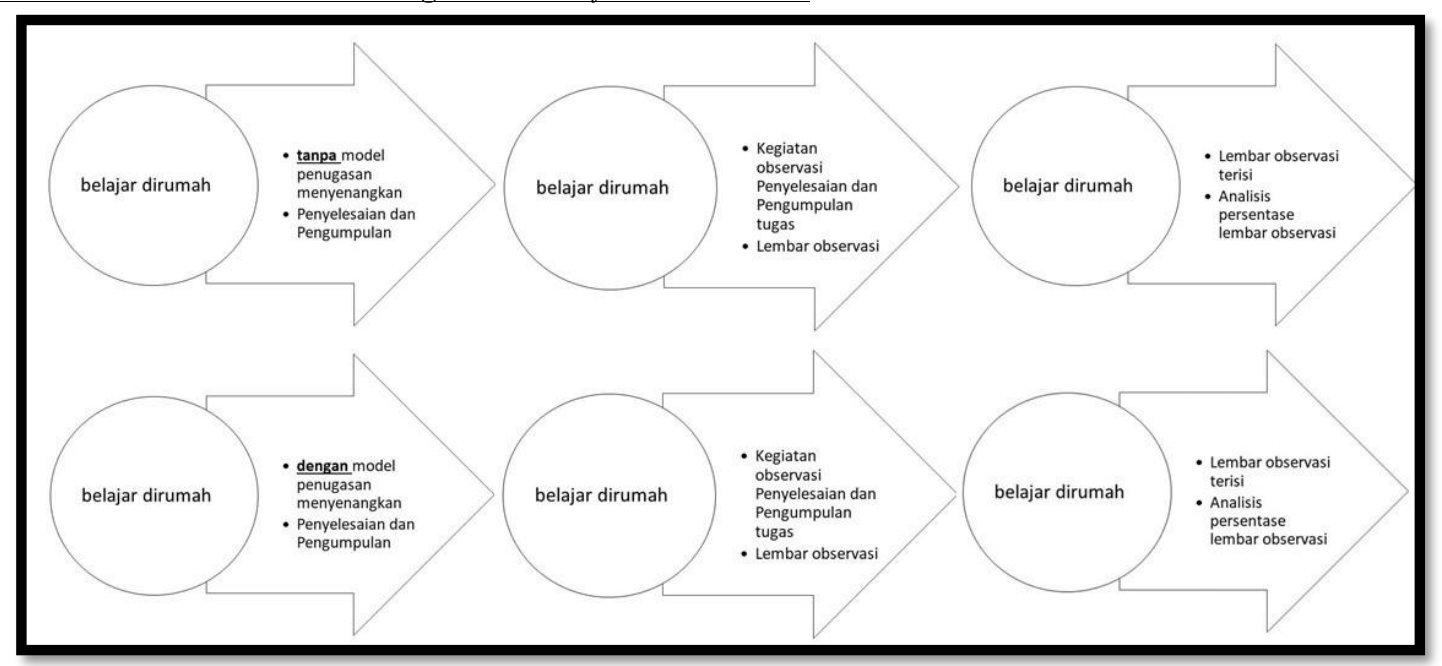

Gambar 1. Grafik Analisis Penelitian

\section{HASIL}

Hasil penelitian model penugasan belajar di rumah yang menyenangkan bagi siswa di masa pandemi Covid 19 digunakan untuk pedoman proses pengambilan keputusan. (Siregar, Ameilia Zuliyanti dan Harahap, Nurliana.2019:90-91) Hasil penelitian model penugasan belajar di rumah yang menyenangkan bagi siswa di masa pandemi Covid 19 dipaparkan dalam Gambar 2. Tabel Rekapitulasi Pengumpulan Tugas Kegiatan Belajar di Rumah tanpa Model Penugasan Menyenangkan https://www.slideshare.net/nurkholisoke/panduan-penialan-sd-2016-kurtilas dan

Adapun Rekapitulasi Pengumpulan Tugas Kegiatan Belajar di Rumah dengan Model Penugasan Menyenangkan terdapat pada Gambar 4. Tabel Rekapitulasi Pengumpulan Tugas Kegiatan Belajar di Rumah dengan Model Penugasan Menyenangkan. (Kemdikbud, Ditjen DikDasMen, 2016: 20)

Gambar 2. Tabel Rekapitulasi Pengumpulan Tugas Kegiatan Belajar di Rumah tanpa Model Penugasan Menyenangkan

\begin{tabular}{|c|c|c|c|c|c|c|c|c|c|c|c|c|c|}
\hline \multirow{2}{*}{ No } & \multirow{2}{*}{ Nama } & \multicolumn{2}{|c|}{ 13-Apr-20 } & \multicolumn{2}{|c|}{ 14-Apr-20 } & \multicolumn{2}{|c|}{ 15-Apr-20 } & \multicolumn{2}{|c|}{ 16-Apr-20 } & \multicolumn{2}{|c|}{ 17-Apr-20 } & \multicolumn{2}{|c|}{ 18-Apr-20 } \\
\hline & & ya & tidak & ya & tidak & ya & tidak & ya & tidak & ya & tidak & ya & tidak \\
\hline 1 & AGHNIA F. & $\mathrm{v}$ & & $\mathrm{v}$ & & $\mathrm{v}$ & & $\mathrm{v}$ & & & $\mathrm{x}$ & $\mathrm{v}$ & \\
\hline 2 & AHMAD D. & & $\mathrm{x}$ & $\mathrm{v}$ & & & $\mathrm{x}$ & $\mathrm{v}$ & & $\mathrm{v}$ & & & $\mathrm{x}$ \\
\hline 3 & AISYA I. & $\mathrm{v}$ & & $\mathrm{v}$ & & $\mathrm{v}$ & & $\mathrm{v}$ & & $\mathrm{v}$ & & $\mathrm{v}$ & \\
\hline 4 & ALFAN F. & $\mathrm{v}$ & & $\mathrm{v}$ & & $\mathrm{v}$ & & $\mathrm{v}$ & & $\mathrm{v}$ & & $\mathrm{v}$ & \\
\hline 5 & ALMIRA R. & $\mathrm{v}$ & & $\mathrm{v}$ & & $\mathrm{v}$ & & $\mathrm{v}$ & & & $\mathrm{x}$ & $\mathrm{v}$ & \\
\hline 6 & ALMIRA V. & $\mathrm{v}$ & & $\mathrm{v}$ & & $\mathrm{v}$ & & $\mathrm{v}$ & & $\mathrm{v}$ & & $\mathrm{v}$ & \\
\hline 7 & ALVINA K. & $\mathrm{v}$ & & $\mathrm{v}$ & & $\mathrm{v}$ & & $\mathrm{v}$ & & $\mathrm{v}$ & & $\mathrm{v}$ & \\
\hline
\end{tabular}


Slamet Basuki. Model Penugasan Belajar di Rumah

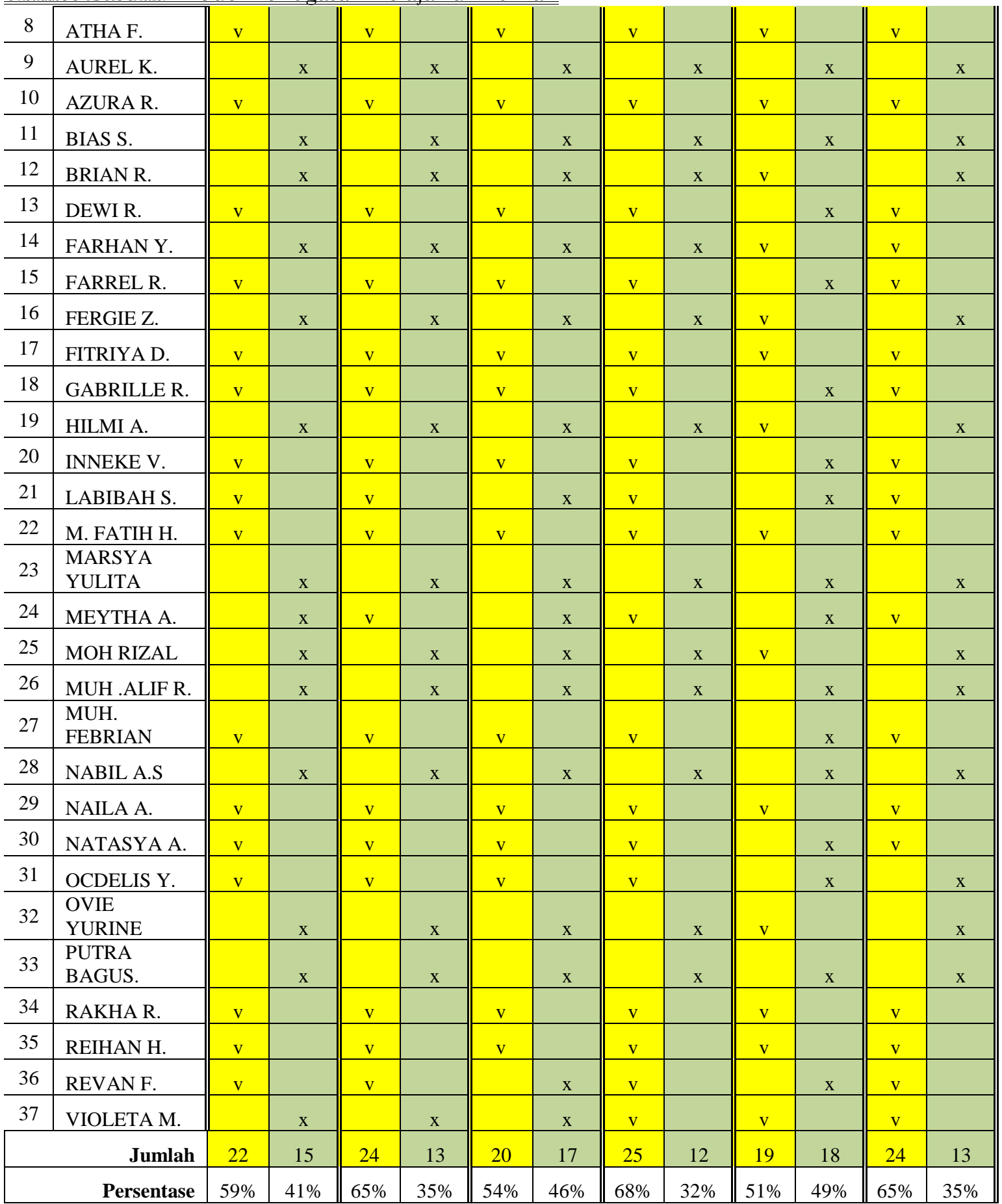


Slamet Basuki. Model Penugasan Belajar di Rumah

\section{Gambar 3. Grafik Pengumpulan Tugas Kegiatan Belajar di Rumah tanpa Model Penugasan Menyenangkan}

30

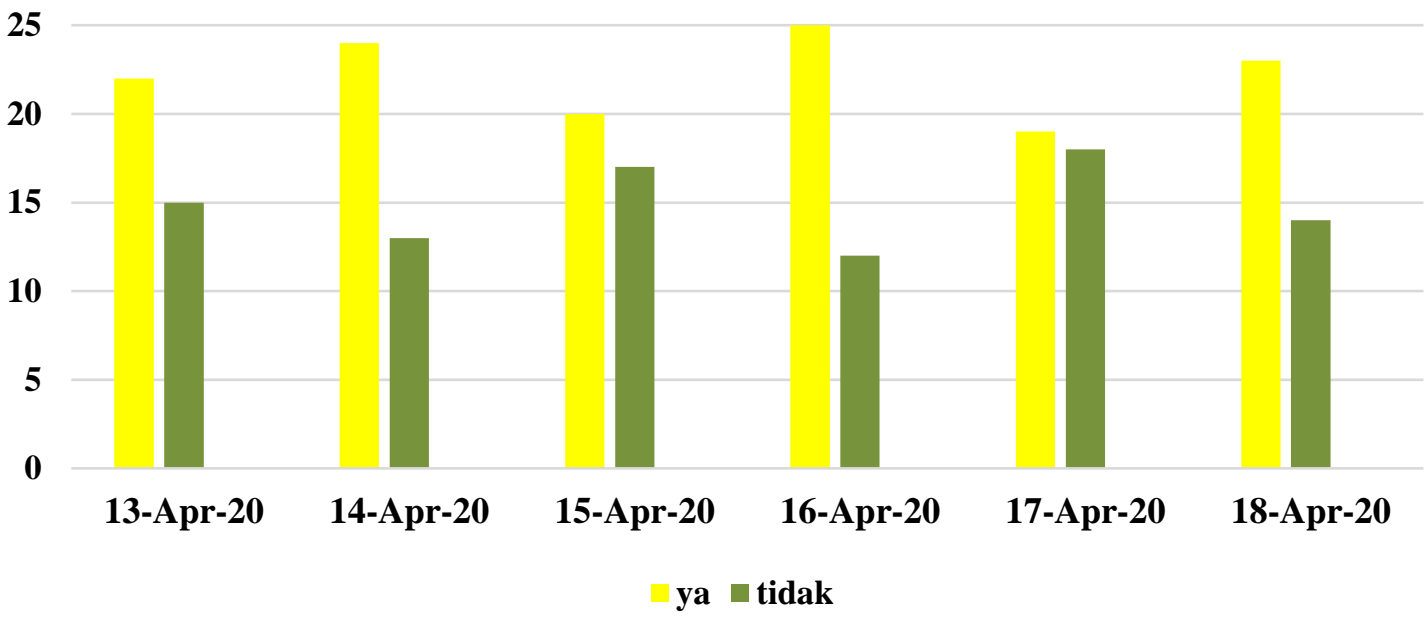

Sumber : Sadikin, Ali. 2016

Gambar 4. Tabel Rekapitulasi Pengumpulan Tugas Kegiatan Belajar di Rumah dengan Model Penugasan Menyenangkan

\begin{tabular}{|c|c|c|c|c|c|c|c|c|c|c|c|c|c|}
\hline \multirow{2}{*}{ No } & \multirow{2}{*}{ Nama } & \multicolumn{2}{|c|}{ 20-Apr-20 } & \multicolumn{2}{|c|}{ 21-Apr-20 } & \multicolumn{2}{|c|}{ 22-Apr-20 } & \multicolumn{2}{|c|}{ 23-Apr-20 } & \multicolumn{2}{|c|}{ 24-Apr-20 } & \multicolumn{2}{|c|}{ 25-Apr-20 } \\
\hline & & ya & tidak & ya & tidak & ya & tidak & ya & tidak & ya & tidak & ya & tidak \\
\hline 1 & AGHNIA F. & $\mathrm{v}$ & & $\mathrm{v}$ & & $\mathrm{v}$ & & $\mathrm{v}$ & & & & $\mathrm{v}$ & \\
\hline 2 & AHMAD D. & $\mathrm{v}$ & & $\mathrm{v}$ & & $\mathrm{v}$ & & & $\mathrm{x}$ & $\mathrm{v}$ & & $\mathrm{v}$ & \\
\hline 3 & AISYA I. & $\mathrm{v}$ & & $\mathrm{v}$ & & $\mathrm{v}$ & & $\mathrm{v}$ & & $\mathrm{v}$ & & $\mathrm{v}$ & \\
\hline 4 & ALFAN F. & $\mathrm{v}$ & & $\mathrm{v}$ & & $\mathrm{v}$ & & $\mathrm{v}$ & & $\mathrm{v}$ & & $\mathrm{v}$ & \\
\hline 5 & ALMIRA R. & $\mathrm{v}$ & & $\mathrm{v}$ & & $\mathrm{v}$ & & $\mathrm{v}$ & & & & $\mathrm{v}$ & \\
\hline 6 & ALMIRA V. & $\mathrm{v}$ & & $\mathrm{v}$ & & $\mathrm{v}$ & & $\mathrm{v}$ & & $\mathrm{v}$ & & $\mathrm{v}$ & \\
\hline 7 & ALVINA K. & $\mathrm{v}$ & & $\mathrm{v}$ & & $\mathrm{v}$ & & $\mathrm{v}$ & & $\mathrm{v}$ & & $\mathrm{v}$ & \\
\hline 8 & ATHA F. & $\mathrm{v}$ & & $\mathrm{v}$ & & $\mathrm{v}$ & & $\mathrm{v}$ & & $\mathrm{v}$ & & $\mathrm{v}$ & \\
\hline 9 & AUREL K. & & $\mathrm{x}$ & $\mathrm{v}$ & & $\mathrm{v}$ & & $\mathrm{v}$ & & & & $\mathrm{v}$ & \\
\hline 10 & AZURA R. & $\mathrm{v}$ & & $\mathrm{v}$ & & $\mathrm{v}$ & & $\mathrm{v}$ & & $\mathrm{v}$ & & $\mathrm{v}$ & \\
\hline 11 & BIAS S. & & $\mathrm{x}$ & & $\mathrm{x}$ & $\mathrm{v}$ & & $\mathrm{v}$ & & & & $\mathrm{v}$ & \\
\hline 12 & BRIAN R. & & $\mathrm{x}$ & & $\mathrm{x}$ & $\mathrm{v}$ & & $\mathrm{v}$ & & $\mathrm{v}$ & & $\mathrm{v}$ & \\
\hline 13 & DEWI R. & $\mathrm{v}$ & & $\mathrm{v}$ & & $\mathrm{v}$ & & $\mathrm{v}$ & & & & $\mathrm{v}$ & \\
\hline 14 & FARHAN Y. & $\mathrm{v}$ & & & $\mathrm{x}$ & $\mathrm{v}$ & & $\mathrm{v}$ & & $\mathrm{v}$ & & $\mathrm{v}$ & \\
\hline 15 & FARREL R. & $\mathrm{v}$ & & $\mathrm{v}$ & & $\mathrm{v}$ & & $\mathrm{v}$ & & & & $\mathrm{v}$ & \\
\hline 16 & FERGIE Z. & $\mathrm{v}$ & & & $\mathrm{x}$ & $\mathrm{v}$ & & $\mathrm{v}$ & & $\mathrm{v}$ & & $\mathrm{v}$ & \\
\hline 17 & FITRIYA D. & $\mathrm{v}$ & & $\mathrm{v}$ & & $\mathrm{v}$ & & $\mathrm{v}$ & & $\mathrm{v}$ & & $\mathrm{v}$ & \\
\hline 18 & GABRILLE R. & $\mathrm{v}$ & & $\mathrm{v}$ & & $\mathrm{v}$ & & $\mathrm{v}$ & & & & $\mathrm{v}$ & \\
\hline 19 & HILMI A. & $\mathrm{v}$ & & $\mathrm{v}$ & & $\mathrm{v}$ & & $\mathrm{v}$ & & $\mathrm{v}$ & & $\mathrm{v}$ & \\
\hline 20 & INNEKE V. & $\mathrm{v}$ & & $\mathrm{v}$ & & $\mathrm{v}$ & & $\mathrm{v}$ & & & & $\mathrm{v}$ & \\
\hline
\end{tabular}


Slamet Basuki. Model Penugasan Belajar di Rumah

\begin{tabular}{|c|c|c|c|c|c|c|c|c|c|c|c|c|c|}
\hline 21 & LABIBAH S. & $\mathrm{v}$ & & $\mathrm{v}$ & & $\mathrm{v}$ & & $\mathrm{v}$ & & & & $\mathrm{v}$ & \\
\hline 22 & M. FATIH H. & $\mathrm{v}$ & & $\mathrm{v}$ & & $\mathrm{v}$ & & $\mathrm{v}$ & & $\mathrm{v}$ & & $\mathrm{v}$ & \\
\hline 23 & MARSYA Y. & & $\mathrm{x}$ & $\mathrm{v}$ & & & $\mathrm{x}$ & $\mathrm{v}$ & & & & $\mathrm{v}$ & \\
\hline 24 & $\begin{array}{l}\text { MEYTHA } \\
\text { AYU. }\end{array}$ & & $\mathrm{x}$ & $\mathrm{v}$ & & $\mathrm{v}$ & & $\mathrm{v}$ & & & & $\mathrm{v}$ & \\
\hline 25 & MOH RIZAL & & $\mathrm{x}$ & & $\mathrm{x}$ & & $\mathrm{x}$ & $\mathrm{v}$ & & $\mathrm{v}$ & & $\mathrm{v}$ & \\
\hline 26 & MUH .ALIF R. & & $\mathrm{x}$ & & $\mathrm{x}$ & & $\mathrm{x}$ & $\mathrm{v}$ & & & & $\mathrm{v}$ & \\
\hline 27 & $\begin{array}{l}\text { MUH. } \\
\text { FEBRIAN }\end{array}$ & $\mathrm{v}$ & & $\mathrm{v}$ & & $\mathrm{v}$ & & $\mathrm{v}$ & & & & $\mathrm{v}$ & \\
\hline 28 & NABIL A.S & $\mathrm{v}$ & & $\mathrm{v}$ & & $\mathrm{v}$ & & $\mathrm{v}$ & & & & $\mathrm{v}$ & \\
\hline 29 & NAILA A. & $\mathrm{v}$ & & $\mathrm{v}$ & & $\mathrm{v}$ & & $\mathrm{v}$ & & $\mathrm{v}$ & & $\mathrm{v}$ & \\
\hline 30 & NATASYA A. & $\mathrm{v}$ & & $\mathrm{v}$ & & $\mathrm{v}$ & & $\mathrm{v}$ & & & & $\mathrm{v}$ & \\
\hline 31 & OCDELIS Y. & $\mathrm{v}$ & & $\mathrm{v}$ & & $\mathrm{v}$ & & $\mathrm{v}$ & & & & $\mathrm{v}$ & \\
\hline 32 & OVIE YURINE & $\mathrm{v}$ & & $\mathrm{v}$ & & $\mathrm{v}$ & & $\mathrm{v}$ & & $\mathrm{v}$ & & $\mathrm{v}$ & \\
\hline 33 & $\begin{array}{l}\text { PUTRA } \\
\text { BAGUS. } \\
\end{array}$ & $\mathrm{v}$ & & $\mathrm{v}$ & & $\mathrm{v}$ & & $\mathrm{v}$ & & & & $\mathrm{v}$ & \\
\hline 34 & RAKHA R. & $\mathrm{v}$ & & $\mathrm{v}$ & & $\mathrm{v}$ & & $\mathrm{v}$ & & $\mathrm{v}$ & & $\mathrm{v}$ & \\
\hline 35 & REIHAN H. & $\mathrm{v}$ & & $\mathrm{v}$ & & $\mathrm{v}$ & & $\mathrm{v}$ & & $\mathrm{v}$ & & $\mathrm{v}$ & \\
\hline 36 & REVAN F. & $\mathrm{v}$ & & $\mathrm{v}$ & & $\mathrm{v}$ & & $\mathrm{v}$ & & & & $\mathrm{v}$ & \\
\hline 37 & VIOLETA M. & $\mathrm{v}$ & & $\mathrm{v}$ & & $\mathrm{v}$ & & $\mathrm{v}$ & & $\mathrm{v}$ & & $\mathrm{v}$ & \\
\hline & Jumlah & 30 & 7 & 31 & 6 & 34 & 3 & 36 & 1 & 37 & 0 & 37 & 0 \\
\hline & Persentase & $81 \%$ & $19 \%$ & $84 \%$ & $16 \%$ & $92 \%$ & $8 \%$ & $97 \%$ & $3 \%$ & $100 \%$ & $0 \%$ & $100 \%$ & $0 \%$ \\
\hline
\end{tabular}

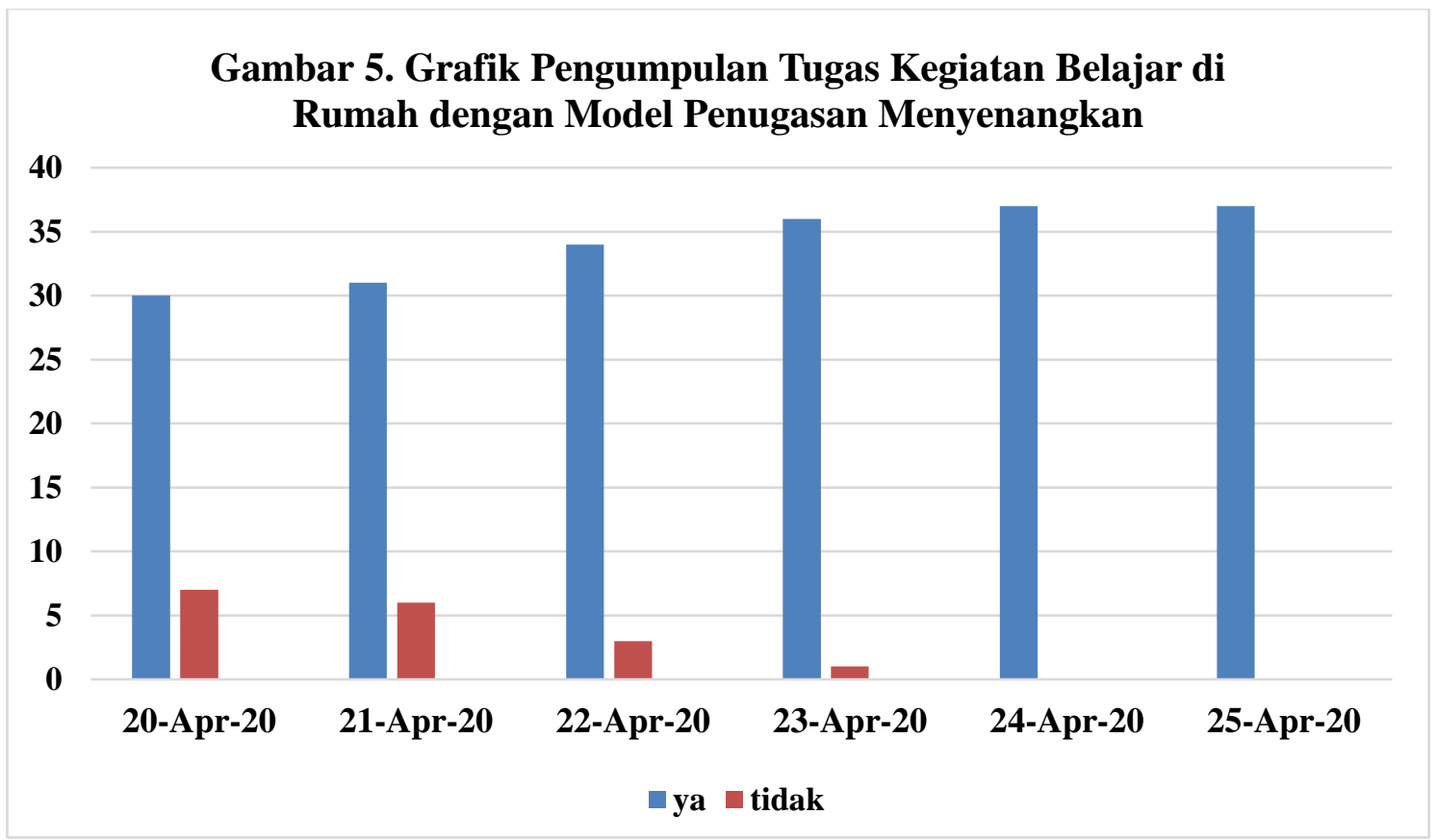

\section{PEMBAHASAN}

Berdasarkan data Rekapitulasi Pengumpulan Tugas Kegiatan Belajar di Rumah tanpa Model Penugasan Menyenangkan yang terdapat pada Gambar 2 dan Gambar 3 
Slamet Basuki. Model Penugasan Belajar di Rumah

partisipasi siswa dalam mengumpulkan tugas masih kurang dengan persentase di bawah $70 \%$.atau hanya 68\% sekitar 25 siswa dari 37 siswa. Pada Gambar 2, untuk hari Senin, 13 April 2020 terdapat 22 siswa atau $59 \%$ dari jumlah siswa yang mengumpulkan tugas, dan 15 siswa atau $41 \%$ dikategorikan tidak mengumpulkan tugas. Selanjutnya hari Selasa, 14 April 2020 mengalami peningkatan dibanding hari Senin, yaitu $65 \%$ atau 24 siswa yang mengumpulkan tugas dan yang tidak mengumpulkan tugas mengalami penurunan menjadi $35 \%$ atau 13 siswa. Hari Rabu, 15 April 2020 jumlah siswa yang mengumpulkan tugas turun menjadi 20 siswa atau $54 \%$ dan yang tidak mengumpulkan menjadi 17 siswa atau $46 \%$.

Data pengumpulan tugas hari Kamis, 16 April 2020 kembali mengalami peningkatan yang signifikan daripada hari sebelumnya sebesar $68 \%$ atau 25 siswa dan yang tidak mengumpulkan tugas sebesar 12 siswa atau $32 \%$, dan merupakan capaian tertinggi dari rentang waktu tanggal 13 - 18 April 2020. Untuk hari Jumat, 17 April 2020 mengalami persentase terendah dalam pengumpulan tugas yaitu $51 \%$ yaitu 19 siswa dari 37 siswa, lainnya 18 siswa atau 49\% tidak mengumpulkan tugas. Terdapat 24 siswa atau $65 \%$ yang mengumpulkan tugas dan 13 siswa atau $35 \%$ untuk hari Sabtu, 18 April 2020. Adapun rata - rata persentase pengumpulan tugas periode 13-18 April 2020 adalah $59,83 \%$ atau 22 siswa. Berdasarkan uraian di atas dapat disimpulkan tingkat partisipasi siswa dalam pengumpulan tugas masih kurang optimal.

Selanjutnya pada gambar 4 dan 5 tabel dan grafik Rekapitulasi Pengumpulan Tugas Kegiatan Belajar di Rumah dengan Model Penugasan Menyenangkan dapat dipaparkan sebagai berikut. Untuk hari Senin, 20 April 2020 terdapat 30 siswa atau $80 \%$ yang mengumpulkan tugas, namun sebaliknya ada 7 siswa atau $19 \%$ yang tidak mengumpulkan tugas. Data hari Selasa, 21 April 2020 ada 31 siswa atau $84 \%$ untuk siswa yang mengumpulkan tugas dan ada 6 siswa atau $16 \%$ yang dikategorikan tidak mengumpulkan tugas.

Adapun hari Rabu, 22 April 2020 terdapat 34 siswa atau $92 \%$ dikategorikan mengumpulkan tugas, meningkat daripada hari Selasa, 21 April 2020 dan ada 3 siswa atau $8 \%$ yang tidak mengumpulkan tugas. Selanjutnya data hari Kamis, 23 April 2020 $97 \%$ atau 36 siswa mengumpulkan tugas dan hanya ada 1 siswa atau $3 \%$ tidak mengumpulkan tugas. Pengumpulan tugas kegiatan belajar di rumah dengan model penugasan menyenangkan mengalami kenaikan yang signifikan dalam partisipasi 
Slamet Basuki. Model Penugasan Belajar di Rumah

pengumpulan tugas. Untuk persentase terendah pengumpulan tugas pada tanggal 20 April 2020 yaitu $81 \%$ atau 30 siswa dari 37 siswa. Adapun pengumpulan tugas dengan persentase maksimal atau 100\% (37 siswa) terdapat pada tanggal 24 dan 25 April 2020. Dengan demikian rata - rata persentase pengumpulan tugas periode 20-25 April 2020 adalah 35 siswa atau $92,33 \%$.

\section{SIMPULAN}

Dengan demikian dari hasil pembahasan tersebut dapat disimpulkan adanya kenaikan yang signifikan partisipasi siswa dalam pengumpulan tugas dalam kegiatan belajar di rumah dengan model penugasan menyenangkan. Hal ini tampak pada rata - rata persentase pengumpulan tugas tugas kegiatan belajar di rumah tanpa model penugasan menyenangkan yang hanya 22 siswa atau 59,83\% dan rata - rata persentase rekapitulasi pengumpulan tugas kegiatan belajar di rumah dengan model penugasan menyenangkan sebesar 35 siswa atau $92,33 \%$.

\section{DAFTAR RUJUKAN}

Alfianika, Ninit.2018. Buku Ajar Metode Penelitian Pengajaran Bahasa Indonesia. Yogyakarta : Deepublisher

Anggito, Albi \& Setiawan, Johan, S. Pd. 2018. Metodologi Penelitian Kualitatif . Sukabumi : CV. Jejak

Arikunto, Suharaimi, 2006. Prosedur Penelitian : Suatu Pendekatan Praktik. Jakarta : PT Rineka Cipta

Gunawan, Imam. 2013. Metode penelitian kualitatif. Jakarta: Bumi Aksara

Helaluddin, Hengki Wijaya. 2019. Analisis Data Kualitatif: Sebuah Tinjauan Teori \& Praktik. Jakarta : STT Jaffray

Kamus Besar Bahasa Indonesia (KBBI), online (https://kbbi.web.id/pandemi) Accesed on Juni 21th 2020.

Kementerian Pendidikan Dan Kebudayaan Republik Indonesia Surat Edaran Menteri Pendidikan dan Kebudayaan Republik Indonesia Nomor 4 Tahun 2020 tentang Pelaksanaan Kebijakan Pendidikan dalam Masa Darurat Penyebaran Coronavirus Disease (Covid-19). Jakarta: Kemdikbud

Kementrian Pendidikan dan Kebudayaan, 2016. Panduan Penilaian untuk Sekolah Dasar (SD)Edisi Revisi. Jakarta : Direktorat Pembinaan Sekolah Dasar, Direktorat Jenderal Pendidikan Dasar dan Menengah

Kompasiana.com.(https://www.kompasiana.com/bungram/5e73a2b3d541df661968fe32/ tentang-belajar-di-rumah) Accesed on Juni 22th 2020. 
Slamet Basuki. Model Penugasan Belajar di Rumah

Kompas.com dalam https://nasional.kompas.com/read/2020/03/03/06314981/faktalengkap-kasus-pertama-virus-corona-di-indonesia?page=all, Accesed on Juni 15 th 2020.

Kurikulum Darurat, 2020. Kalender Pendidkan SDN Sukorame 3 Kediri: 2020 tidak diterbitkan.

Mamik, 2015. Metodologi Kualitatif. Sidoarjo : Zifatama Publishing

Kementerian Pendidikan dan Kebudayaan, 2016. Panduan Penilaian untuk Sekolah Dasar (SD)Edisi Revisi. https://www.slideshare.net/nurkholisoke/panduanpenialan-sd-2016-kurtilas Accesed on Juni 17th 2020.

Rahardjo, Ilham 2020. Model Penugasan Menyenangkan di Masa Pandemi Covid 19. LPMP Jawa Timur. Surabaya: Tidak diterbitkan

Sadikin, Ali. 2016 https://alisadikinwear.wordpress.com/2012/07/16/laporan-penelitiantindakan-kelas-1/ Accesed on Juni 17th 2020

SDN Sukorame 3 Kediri, 2019; Buku Data Kelas 5 Tahun Pelajaran 2019/2020. Kediri Tidak diterbitkan.

Siregar, Ameilia Zuliyanti dan Harahap, Nurliana. 2019. Strategi Dan Teknik Penulisan Karya Tulis Ilmiah Dan Publikasi, Yogyakarta : Deepublisher

Sutrisno dan Fanani, Achmad 2016. Kamus Lengkap Inggris-Indonesia IndonesiaInggris. Jakarta : Senja Publishing

Google Translate. online.https://translate.google.com/?hl=en. Accesed on Juni 22th 2020.

World Health Organization (https://www.who.int/indonesia/news/novel-coronavirus/qafor-public) Accesed on Juni 20th 2020. 